"Treatment strategies for bad loans to microfinancial institutions: evidence from Kendari, Indonesia"

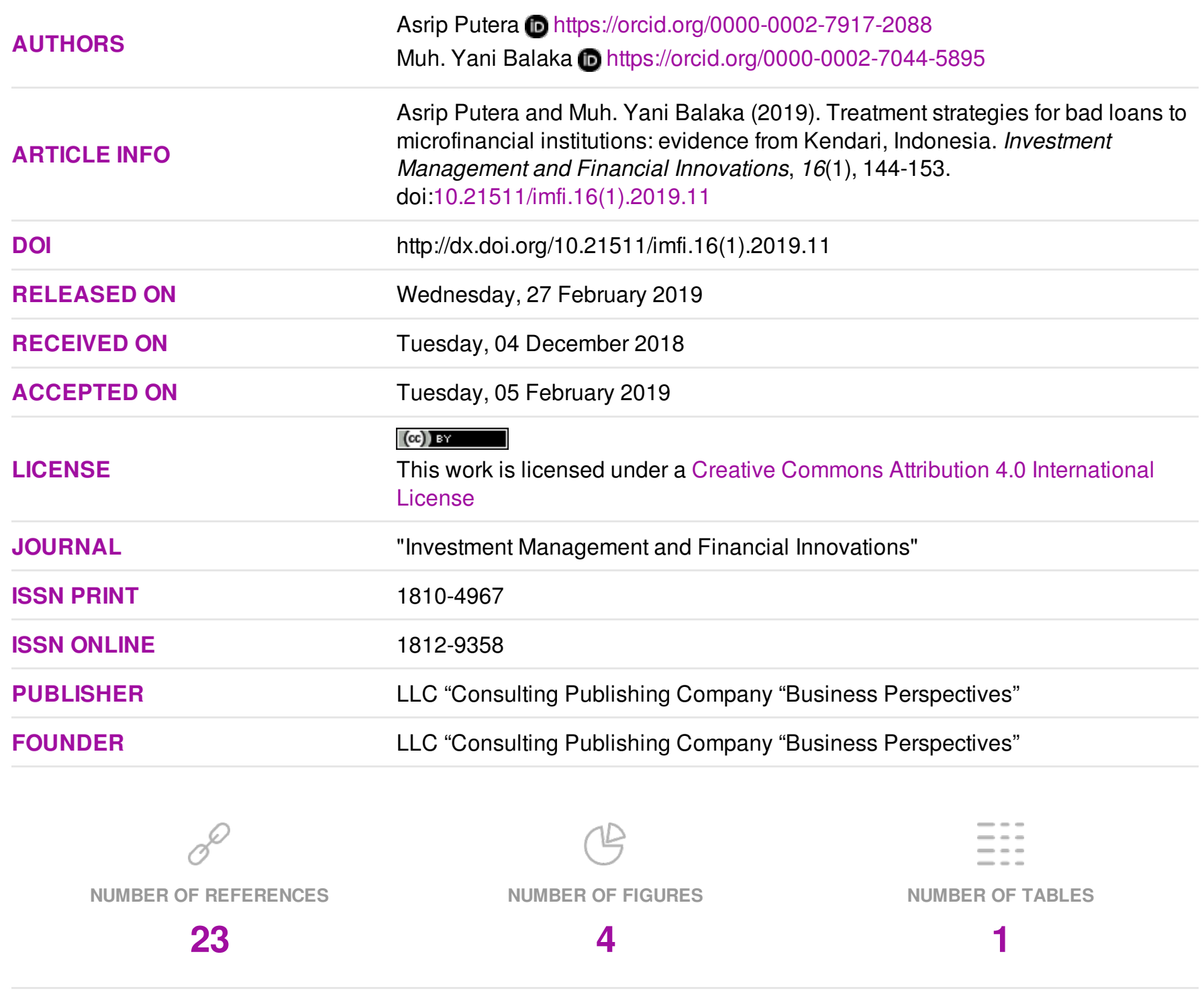

(c) The author(s) 2022. This publication is an open access article. 


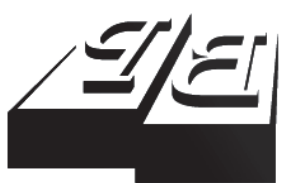

BUSINESS PERSPECTIVES

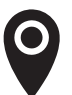

LLC "CPC "Business Perspectives" Hryhorii Skovoroda lane, 10, Sumy, 40022, Ukraine

www.businessperspectives.org

Received on: $4^{\text {th }}$ of December, 2018 Accepted on: $5^{\text {th }}$ of February, 2019

(C) Asrip Putera, Muh. Yani Balaka, 2019

Asrip Putera, Doctor, Lecturer, Faculty of Economics and Business, Halu Oleo University, Kendari, Indonesia.

Muh. Yani Balaka, Doctor, Lecturer, Faculty of Economics and Business, Halu Oleo University, Kendari, Indonesia.

\section{TREATMENT STRATEGIES FOR BAD LOANS TO MICROFINANCIAL INSTITUTIONS: EVIDENCE FROM KENDARI, INDONESIA}

\begin{abstract}
The purpose of the research is to find the right strategic formula to resolve bad loans suitable to environment and characteristics of micro-financial institutions and their consumers. It applies qualitative approach by means of interactive method put forward by Milles and Huberman (2009) as analysis method. Data are obtained from in-depth interview with superordinates, staff and consumers of microfinance institutions in Kendari city. A microcredit institution "Harum" needs several strategies to handle bad loans. It includes: institutional reinforcement (improvement in service procedure, increase in human resources' skill, more branch offices, more new recuitments, the involvement of sub-district government, the use of information system), reinforcement of consumers' capacity (tight selection process, counseling of business management, advisory service, and special relationship). The research results serve as solutions to microfinancial institutions in handling bad loans, from which development and sustainability can be assured. Consumers might make use of this information to develop their business. They also might serve as references for regional government in making the right policy for the development of microfinancial institutions and small business empowerment. This is the first study exploring formulation of strategy for microfinancial institutions in handling bad loans. The research explores internal and external aspects of microfinancial institution, with holistic view of the right policy in terms of institutions and consumers.
\end{abstract}

Keywords credit, microcredit, bank system, market, financial policy

JEL Classification

G21

\section{INTRODUCTION}

The growth of microfinancial institutions provides financial support to small business which commonly suffers from a very limited access to bank. Several issues which are the characteristics of small business such as limited capital, being in non-incorporated status, and traditional management are some reason that explain their uncreditworthiness (Sumodiningrat, 2003). Survey by BPS (National Office of Statistic) lays grounds for categorization of issues small business regularly faces. They are capital (38.3\%), materials $(25.02 \%)$, and marketing (21.3\%) (Statistik, 2014).

The existence of microfinancial institutions is expected to significantly uphold people welfare. Several research has found relationship between microfinancial institution and reduced poverty (Choudhury et al., 2017; Mazumder \& Wencong, 2013). Microfinance can serve as an instrument for empowerment to achieve increased public income and reduced poverty (Saefullah, 2018). Robinson (2001) argues that poverty alleviation can be carried out by means of various programs, one of which is microfinancial service. 


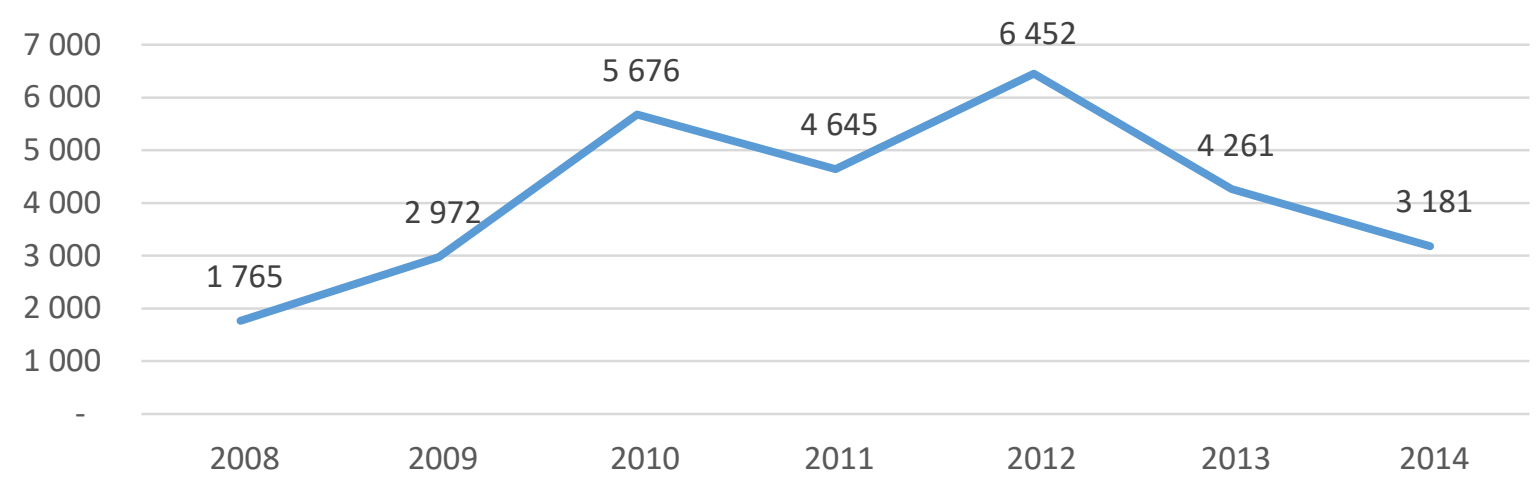

Figure 1. Customer development BLUD of Kendari city micro credit

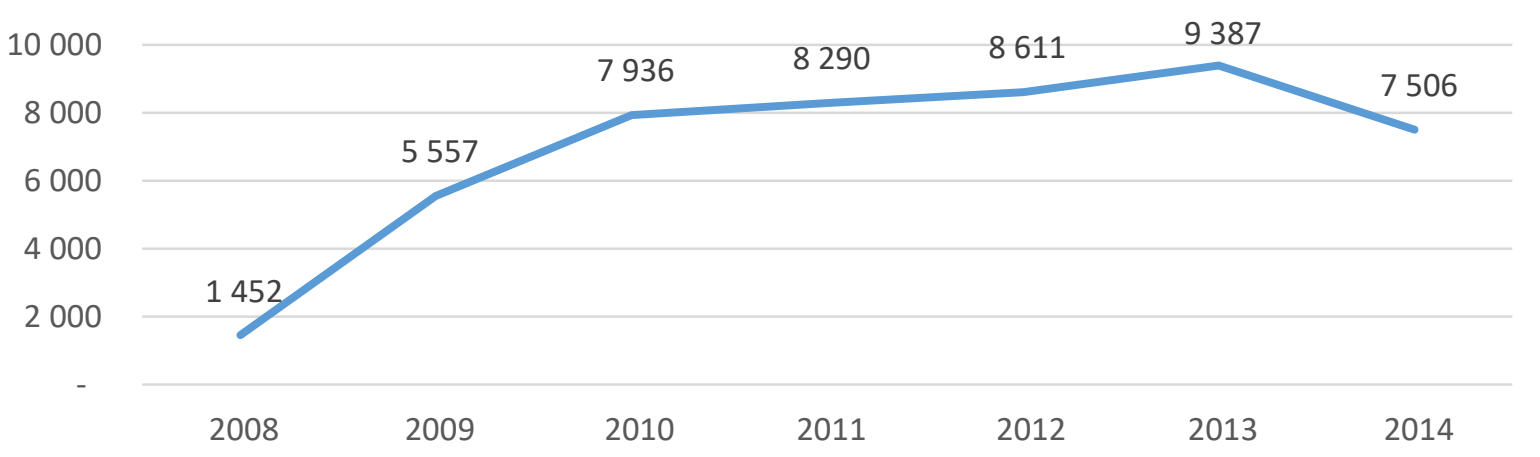

Figure 2. Development of funds distributed (in millions of rupiah)

Microfinance play a significant part to the growth of small business when it is capitalized optimally, including those household businesses run by women (Joseph, 2018). Microfinancial institution has a strategic position in the increase of public welfare, and its service of capital has enabled microfinance to procure necessary equipment, materials, human resource and other investment.

The efficacy of microfinancial institution in poverty alleviation han been noticeable in several developing countries, such as Bangladesh, even though the concept is still in debate (Afonso et al., 2011). In the same vein, Choudhury et al. (2017) prove that microfinancial program has a positive effect on poverty alleviation and the increase of village household competitiveness in Bangladesh, with the result of increased living standard. Another research (Brief, 2015) in Bosnia and Herzegovina find that the efficacy of microfinance is only noticeable in small groups, while in Portugal (Afonso et al., 2011), the estimate of the failure rate of microfinance program was 20.6 percent in 2006-2009. Other research (Lawin, 2018) shows that effects of microfinance tend to be variative depending on the contexts.

In Indonesia, microfinancial program does not do much in uplifting the welfare of wide society. One most conspicuous reason, among others, is bad loans. Bad loan is the risk that comes first to evade in the mind of financing institutions, as it can interrupt their sustainability. Internal and external factors might cause bad loan, and pinpoint that external factors come from customers and economic conditions. Internal factors can derive from staff ignorance or unsupporting system. Incomplete regulation might cause bad loan, such as the absence of ethic code or minimum standard service regulations (Wardana et al., 2017). 
Though the failure stories of microfinance in its effect on the increase of public welfare, its success stories are sufficient to make balance. It explains continued effort by government to increase microfinance role in supporting small businesses. Municipal government of Kendari inspired by Gramen Bank of Bangladesh forms an institution with specialized task of channeling microcredit. The microcredit institution of Regional Public Service Office (Ind. Badan Layanan Umum Daerah - BLUD) is so-called "Harum". It was established in 2008 and has well grown since then. It has had 28,952 consumers with credits distributed as much Rp. 48.740.000.000 - only within 7 years.

The graphics demonstrate that micro credit institutions have managed high growth, which unfortunately they cannot maintain in the long term. This unsustainable growth is mainly due to bad loans in a such considerable extent. Only in March 2017, 76 percent $(2,448)$ of customers suffered from bad loans with total value of Rp. 1.295.644.000 - thus, the issue of ways to return high growth is always intriguing. It entails formulation of the right strategy suitable to environment and the characteristics of microcredit institution and its consumers.

\section{The purpose of the research}

The research is inspired by the fact of pervasive bad loans in microcredit institution, "Harum", in Kendari city. The main purpose of the research is to explore the formulation of strategy of bad loan treatment suitable to environment and characteristics of microcredit institution and its customers, from which the return to its growth and high performance becomes possible.

\section{LITERATURE REVIEW}

\subsection{The importance of microcredit}

Microcredit is one instrument that is considered effective enough to reduce poverty (Banerjee, 2017). Various studies have been conducted in developed countries earlier than in developing countries. Especially in developing countries, poverty is a very urgent problem to get a solution. Studies conducted in Pakistan concluded that microcredit was owned by poverty alleviation. It is further explained that larger families experience higher rates of poverty reduction than small families (Hussain et al., 2018).

However, different studies in Bangladesh found the surprise that microcredit loans had an indirect negative effect on overall life satisfaction through increasing concerns, while other findings we have found are that female micro borrowers experienced increased satisfaction related to financial security. We also provide evidence that micro borrowers with higher asset levels experience increased satisfaction with financial security (Bhuiyan \& Ivlevs, 2018). Another study in three villages in Bangladesh also found that microfinance led to increased levels of debt among already poor communities and exacerbated economic, social and environmental vulnerabilities (Banerjee, 2017).

Research that supports that microcredit is quite effective in alleviating poverty is also carried out in Malasiya. The study was conducted in Selangor by taking a sample of 326 customers from one of the micro-economic institutions between February and April 2016 using descriptive and multiple regression analysis. The research findings show that most customers are married (95.7 percent) and have secondary education (72.7 percent). The results of the analysis show that the variables of family workers and hired workers significantly influence the ratio of income-investment after joining the microcredit program. (Tammili, Mohamed, \& Terano, 2018). Another study conducted in Malasiya took 300 respondents using SmartPLS as an analytical tool to conclude that microcredit programs have an impact on the economy and socety, and environment (Geetha, Savarimuthu, \& Majid, 2017).

Similar study was also conducted in Bangladesh by taking a larger sample of 3,000 households which is one of our customers with the criteria 
that microcredit institutions have a minimum of three times meneyelesaikan borrowing, where the study aims to assess the effectiveness of microfinance in household income, expenditure and savings. The study found that microcredit programs had a significant positive impact on household income, expenditure and savings. In addition, this study revealed that the level of education plays an important and significant role in increasing household income, expenditure and savings (Choudhury et al., 2017). Another study from Pakistan concluded that microfinance institutions have been superior in poverty alleviation and empowerment than conventional financial system approaches (Khan, Shaorong, \& Ullah, 2017).

\subsection{Bad credit and settlement strategy}

One of the problems in microcredit institutions is the high level of bad credit. Various studies have been conducted to analyze the factors causing the occurrence of bad credit. A study was conducted in the Western Region of Ghana, using primary data from a survey of 200 small entrepreneurs. The results show that company size, interest rate, loan duration, profit rate and loan amount are the determining factors for the occurrence of non-performing loans simultaneously. The study recommends the need to intensify training programs that aim to improve employers' managerial and technical capabilities to ensure healthy and productive management to promote company growth and increase profit margins (Abu et al., n.d.).

A study conducted in Kenya concluded several strategies in resolving bad loans. Some policy recommendations such as microfinance must also avoid lending to risky customers or for speculative ventures, monitor loan payments, and renegotiate loans whenever the borrower experiences difficulties (Ambundo \& Anddr, 2017). In line with that, research conducted on a small bank in Indonesia concluded that there are two ways to settle bad credit, namely litigation efforts through the court and non-litigation efforts through preventive efforts, namely actions to anticipate the emergence of bad credit, early warning, and negotiation efforts (Puspita, n.d.).

\section{RESEARCH METHOD}

\subsection{Research object}

The research focuses on microcredit institution "Harum" in Kendari city given that it is the only institution which provides microcredit service to small business without guarantee, and which is formed by Kendari municipal government.

\subsection{The choice and determination of informants}

Qualitative approach emphasizes the number of information rather than that of informants, on the basis of which the number of informants is not the issue as long as the information gathered has been sufficient and valid (Fatchan, 2011). In order to get accurate and valid information, it is pivotal to find informants with direct experience or who are the parts of an event. Informants in this research are composed of superordinates and surveyor, and consumers.

Table 1. The list of research informants

\begin{tabular}{|c|c|c|c|}
\hline \multicolumn{4}{|c|}{ Superordinates and staff as informants } \\
\hline No. & Name & Positions & $\begin{array}{l}\text { Year of } \\
\text { holding } \\
\text { position }\end{array}$ \\
\hline 1 & $\begin{array}{l}\text { Drs. Askin, } \\
\text { BC. Ku }\end{array}$ & $\begin{array}{l}\text { The chief of business } \\
\text { promotion and } \\
\text { development division }\end{array}$ & 2013 \\
\hline 2 & Manser & $\begin{array}{l}\text { Staff of business promotion } \\
\text { and development }\end{array}$ & 2008 \\
\hline 3 & Sulasman & $\begin{array}{l}\text { Staff of business promotion } \\
\text { and development }\end{array}$ & 2009 \\
\hline \multicolumn{4}{|c|}{ Consumers as informants } \\
\hline No. & Name & Business & $\begin{array}{l}\text { The length } \\
\text { of being } \\
\text { customer }\end{array}$ \\
\hline 1 & Ina-ina & Coster & 2 \\
\hline 2 & Suharmimi & Basic need product seller & 3 \\
\hline 3 & $\begin{array}{l}\text { Daeng } \\
\text { Matu }\end{array}$ & Fishmonger & 3 \\
\hline
\end{tabular}

\subsection{Data gathering technique}

Data and information required for the research are gathered by the following methods:

1) observations (before and after interview):

- researchers make observations in the field both before and after interview concerning 
activities in microcredit institution of regional public service office, including activities of consumers;

2) in-depth interviews:

interviews are perfomed in the institution (for superordinates and staff) twice by making appointment: first, they are semi-structured and nonstructured in the duration of over 60-90 minutes, while interviews with consumers are in their business sites;

documentation: researchers gather various data from regional public service office, government, and other trustworthy sources.

\subsection{Data validity}

To assure the quality of research data, researchers carry out test with several criteria, as pointed out by Fatchan (2013). The research performs triangulation in several ways. First, comparing data from observations to those from interviews. Second, comparing understanding of one informant to another (not informant), if researchers feel any difference between them, so confirmation to the informant concerned is necessary.

\subsection{Data analysis}

Data are analyzed by means of interactive technique adopted from Milles and Huberman (2009). Interactive model should go through three stages of analysis.

Data reduction. It is a stage where researchers choose, select, simplify, and categorize data found in the field, either from observation or interview. Next, reseachers make data coding and summary of themes relevant to research focus, by which data which are irrelevant to research focus would be removed.

Data presentation. It is a stage where researchers organize information and describe it in the form of narrative text, matrix, graph, and table.

Drawing conclusions.

\section{ANALYSIS} AND DISCUSSION

Based on observations and in-depth interviews, researchers formulate strategies to handle bad loans in microfinancial institution of Regional Public Service Office, Harum, and Kendari city.

\subsection{Strategies for bad loan treatment in microcredit institution "Harum" in Kendari city}

Based on the analysis on phenomenon, researchers bring up strategies to treat bad loans. They are composed of two types, that is, strategy for microcredit institution, and strategy for consumers.

\section{A Institutional reinforcement}

Organization's internal condition has a close association to bad loan. Thus, strategies should include: service procedure improvement, the increase in human resources skill, more recruitment, information system application, sub-district government involvement, and more offices at district level.

\section{a. Service procedure improvements}

Some improvements could be made regarding to service procedure. They include:

- the necessity of layered supervision on the creditworthiness of future debtors. So far microcredit institution of Regional General Service Office only rely on surveyor for the creditworthiness. The evaluation should involve not only one surveyor, but also other staff whose responsibility is related to consumers' repayment of credit;

- surveyors should not only consider bonus as their motivation to have many consumers. Prudence emphasizes quality that should come first before others. Bonus grant with system that more bonuses come with more consumers should be treated more cautiously. If they are driven to have more consumers because of its bonuses, the selection is no longer strict, with wider possibility of bad loan. 


\section{b. The increase in human resources skill}

Many microfinancial institutions suffer from low skilled staff. There is a common mitchmatch between staff education background and skills required in financial, microcredit and banking sectors. Training, education, and technical counseling pertaining to microcredit is essential for work performance. Knowledgeability in job results in increased creativity and innovation. Training will assure the quality of work. A surveyor needs knowledge-based survey of creditworthiness, from which business sustainability could be manitained and the right target of consumers could be attained for the success of program. In doing so, surveyor should have a deep comprehension of $5 \mathrm{C}$ and $7 \mathrm{P}$ principles in evaluating future customers' creditworthiness. The $\mathrm{C}$ could refer to characters, important for the analysis of people's true personality with its effect on credit repayment prospect.

\section{c. More recruitment}

1) For positions in internal supervisory unit:

- limited number of staff is one issue that should quickly be taken care of as it hampers supervision. As organization that operates in credit channeling to underpriviled society, it needs a well functioning supervision to make sure the channeling runs as intended. The supervision at microfinancial institution "Harum" does not function properly. All positions for Internal Supervisory Unit are still vacant. This condition makes superordinates take over the function of supervision which distorts objectivity and decisions and allows for clash of interests. Organization should have a special division which has its own authority to assure objectivity, consistence, and integrity. In order to control the field work of surveyors, for instance, organization needs a supervision from a special division that is free from interest conflict. The objectivity allows for objective and reasonable evaluation.

2) For surveyor position:

- the number ratio between surveyors and consumers is quite imbalanced, where 14 surveyors serve \pm 6,500 (accumulated) consumers. Measures should be taken to rebalance the position such as increasing the number of surveyors and/or reducing that of consumers. Only by this way, communication and supervision can run in an appropriate manner. An intense communication between consumers and surveyors is critical, as surveyors at microfinancial institution "Harum" perform multi-functions;

- they recruit new consumers;

- they evaluate the future consumers' creditworthiness;

- the collect the credit repayment;

- promotion and support from surveyors will be much appropriately focused if the scope or the number of consumers under their supervision is under limited range. This limited range enables for continuous interaction, consumer' business sustainability, and credit repayment assurance. Above all, the consumer's growing business is related to the success of microfinancial institution program.

\section{c. Information technology application}

In order to be professional and accountable microfinancial institution, the application of information and technology is a must. It means that microfinancial institution of "Harum" should adapt itself to information and technology development. Information and technology application in its operations provides the ease of control, data availability, and forecasting and evaluation supports for institution. These all are important for its effective and efficient operation on which its success relies. They would facilitate supervision, since accurate and complete data and detailed history of all activities and decisions in consumers' business make the track of business prospect much easier. With these on hand, decision accountability can be assured.

\section{d. The involvement of sub-district government}

One of main causes of bad loan is that consumers move their place of living and do not report 


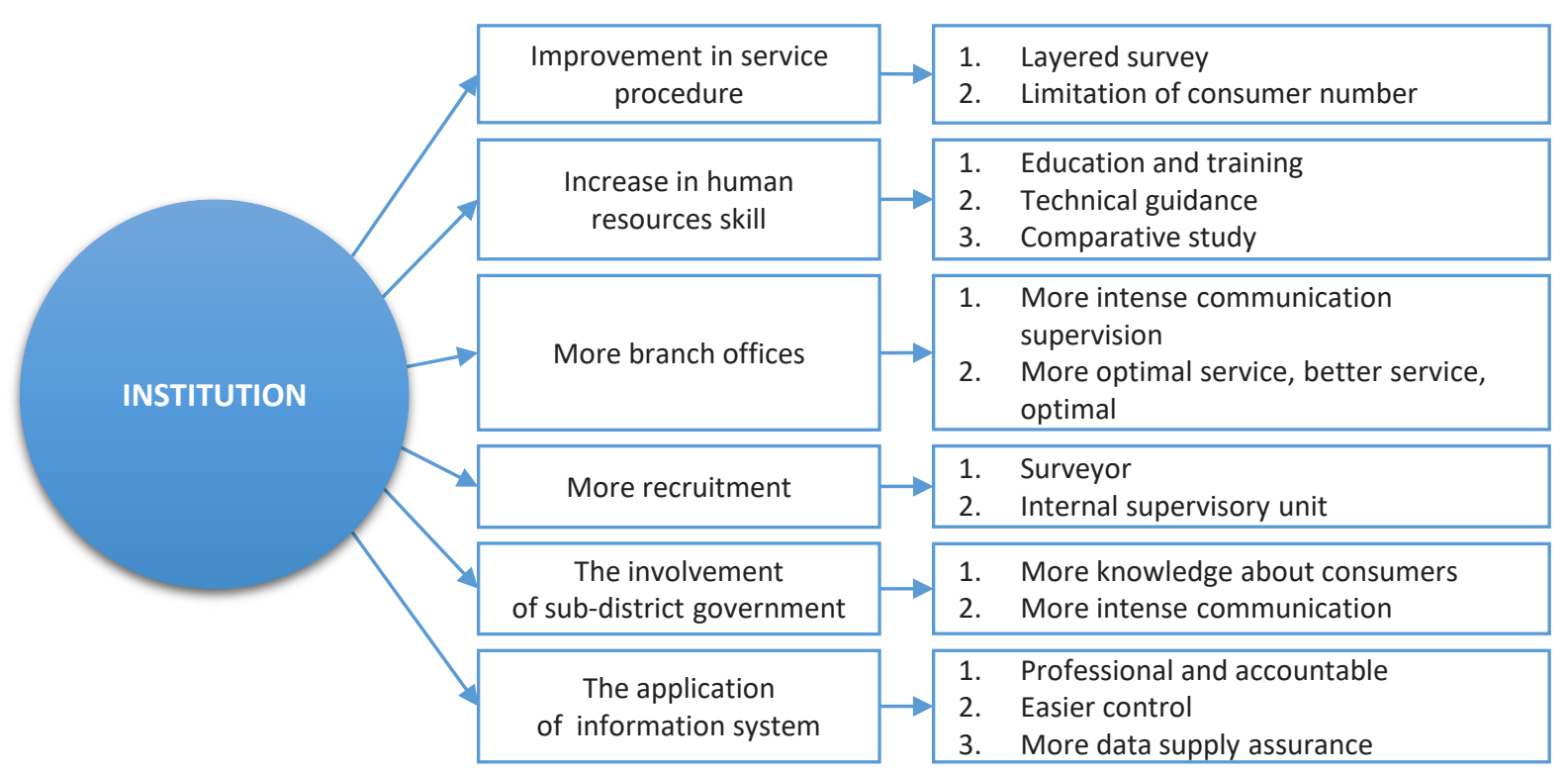

Figure 3. Strategies to improve performance of "Harum" microcredit institution in Kendari city

their new address. It makes surveyor (credit collector) hard to locate their position, and close meaningful relationship becomes possible. They can move to a new place in or outside Kendari city. The involvement of village government (including head of village) in a survey process or supervision on business sustainability or customer existence. They surely know better people living in their neighborhood. Recommendation or clarification from village government (including head of neighborhood) can help ensure identity of candidate consumers. Moving to a new place (outside and inside) in an area requires clarification from village government (including head of village). By means of this clarification, the events of moving to new place by people can be traced, including data of new addresses. By this way, problems caused by place moving can be reduced, especially in relation to supervision for credit repayment assurance and business promotion in a certain area. Consumers can not easily move out any longer without being detected and should inform the new address to village government if chief of neighborhood is made to be part of "Harum" microcredit program.

\section{e. More branch offices at district level}

The centralized service system of "Harum" microcredit institution can not reach all areas in
Kendari. It has no capability to cover them, and it explains its weak control and communication with consumers. More branch offices at district level at least could serve as solution besides supporting qualified human resources. Relationship between consumers and "Harum" microcredit institution could get closer by means of the institution' branch offices presence at district level. The closer distance also enable for the right selection of candidate consumers. Close assistance and support to consumer' business will be much intense and focused if area of monitor is within reach. The staff of "Harum" microcredit institution would more equipped to provide best service in the interest of customer's business sustainability and their subsequent heightened welfare.

\section{B The increase of consumer capacity}

Several problems "Harum" microcredit institution commonly faces are associated to consumers' behaviors. Thus, strategy to apply should be consumer-based. They include a tight selection process, management consultation, close assistance, heightened discipline and regular meeting (intense communication).

\section{f. Management consultation}

Consumers of "Harum" microcredit institution commonly lack the knowledge and skill in 


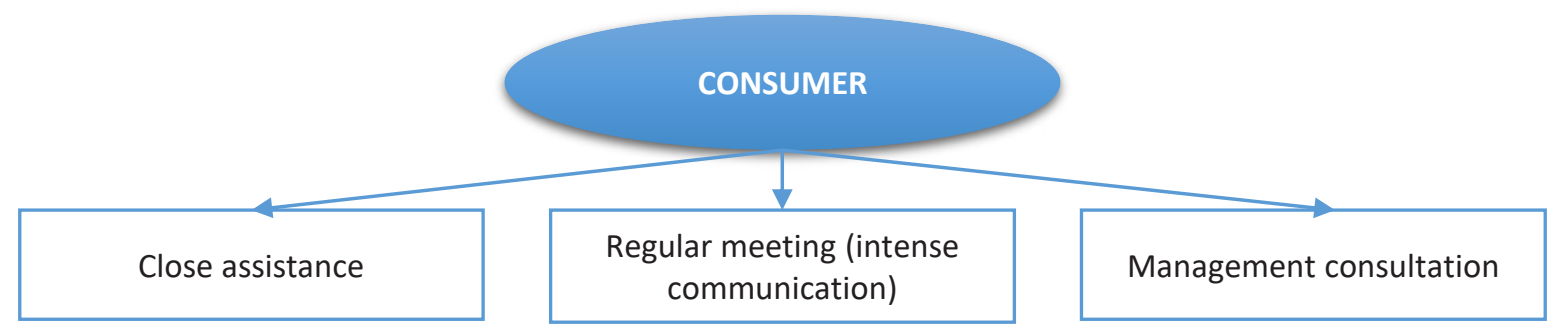

Figure 4. Strategies to increase capacity of "Harum" microcredit institution consumer

management. They mostly come from poor group of society with low education and without necessary experience. Some of them go into business because of no choice left on hand, and still others want see their luck in business. Though driven by various motivation in doing business, consumers have one thing in common, that is, they mostly lack of management knowledge and skill necessary to support their businesses. This can be solved by means of management consultation or training. Management consultation or training should be conducted before and after credit realization. In the former case, they could equip consumers knowledge and skill necessary to ascertain their income and profit required to repay the credit. The success in maintaining the trust of microcredit institution means credit assurance for individual's or whole consumers' business in the future in and for "Harum" microcredit sustainability. In the latter case, they could serve as a drive or motivation in business. Consumers can consult any problems they encounter in dayto-day business practice during management consultation or training. They could learn for solutions made together with surveyors and feel high spirit to continue and develop their business.

\section{g. Close assistance}

Stagnant business might lead to bad loans. Several factors might operate to halt the business. They include inapproapriate management, economic turmoil, and insufficient knowledge and skill. Close assistance offered by "Harum" microcredit institution to consumers is a must for any problems encountered in day-today business operation is aptly handled. The institution could make a close assistance alone or in collaboration with other institutions such as university, cooperative and SME (small and medium enterprises) office, NGO, or other institutions interested in empowerment.

\section{h. Intense communication}

A well and intense relationship between "Harum" microcredit institution represented by surveyor (credit collector) and consumers would lead to useful communication that assures openness and cooperation important to settle down problems between them or in business. This is social capital that drives the both sides to maintain trust. Consumers and surveyor would try their best to not stain their relationship. On consumer part, they would work hard to avoid bad loan from happening by running their business seriously, following the surveyor advices, suggestions and inputs carefully, and learning the state-of-art management. On surveyor part, they would do their best for to help consumer's business develop and sustainable, including solutions to problems consumers usually encounter in their business practices.

\subsection{Limitation and future research}

The present research only focuses on one microcredit institution which belongs to regional government. Future research could explore other institutions with different characteristics. This difference in characteristics can lead to different research results. Research into private institution would enrich the knowledge concerning the nature of relationship between consumers and their microfinancial creditors. 


\section{CONCLUSION}

The strategy for handling bad credit at the microcredit Regional Public Service Agency (BLUD) "Harum", must implement several strategies:

1) institutional strengthening consisting of (1) improvement of service procedures needs to be done so as to provide a clear working mechanism and reduce various risks that may occur, (2) increased HR skills also need to get serious attention so that the ability of employees to work is more productive and efficient, (3) opening of branches needs to be considered so that the range of services is closer to the customer, besides that control and guidance for the customer's business will be more intensive, (4) addition of employees is a mandatory thing so that the workload of employees is lighter so that the control and guidance of the customer's business is more intensive and focused, (5) the involvement of the Village government needs to be increased so that control of customers is more assured, given that customers do not provide guarantees when lending loans, (6) the use of information systems is a very urgent need, it is expected that the use of information systems will provide accountability and high work efficiency;

2) strengthening customer capacity can be achieved by several strategies such as (1) a strict selection process needs to be carried out so that customers who obtain credit facilities from the BLUD are integrity and appropriate customers, (2) extension of business management must be carried out by the BLUD in order to provide understanding and improvement of knowledge related to business management, (3) business assistance/guidance needs to be carried out in ensuring that the customer's business runs well and can immediately find a solution if a problem occurs, (4) increased discipline and friendship must also receive serious attention so that the delay in credit repayments can be minimized.

\section{REFERENCES}

1. Abu, B. M., Domanban, P. B., \& Issahaku, H. (2017). Microcredit Loan Repayment Default among Small Scale Enterprises: A Double Hurdle Approach. Ghana Journal of Development Studies, 14(1), 146165. https://doi.org/10.4314/gjds. v14i1.8

2. Afonso, J. S., Mota, I. G., \& Silva, S. T. (2011). The financial sustainability of microcredit in Portugal. Economics and Management, 1(1), 53-56. Retrieved from http://www.findevgateway. org/library/financial-sustainabilitymicrocredit-portugal

3. Ambundo, D., \& Anddr, M. (2017). Constraints to Growth of Micro Institutions in Nairobi County, Kenya. Finance Constraints To Growth Of Micro Finance Institutions In Nairobi County, Kenya, 2(1), 108-124. Retrieved from https://carijournals.org/ journals/index.php/IJF/article/ view/45
4. Banerjee, S. B. (2017). Microfinance and the business of poverty reduction: Critical perspectives from rural Bangladesh. Human Relations, 70(1). https://doi. org/10.1177/0018726716640865

5. Bhuiyan, M. F., \& Ivlevs, A. (2018, September 27). Microentrepreneurship and subjective well-being: Evidence from rural Bangladesh. Journal of Business Venturing, 1-21. https://doi. org/10.1016/j.jbusvent.2018.09.005

6. Brief, E. I. (2015, August). The impact of microcredit: Evidence from across the world.

7. Choudhury, A. H., Das, A., \& Rahman, A. (2017). The Effectiveness of Micro-credit Programmes Focusing on Household Income, Expenditure and Savings: Evidence From Bangladesh. Journal of Competitiveness, 9(2), 34-44. https:// doi.org/10.7441/joc.2017.02.03
8. Fatchan, A. (2011). Metode Penelitian Kualitatif. Surabaya: Jenggala Pustaka Utama.

9. Fatchan, A. (2013). 10 Langkah Penelitian Kualitatif; Pendekatan Konstruksi dan Fenomenologi. Malang: Universitas Negeri Malang Press.

10. Geetha, C., Savarimuthu, A., \& Majid, A. A. (2017). Assessing financial returns on microloans from economic, social and environment impact: a case of Kota Kinabalu. Malaysian Journal of Business and Economics, 4(2), 7-29. Retrived from https://jurcon.ums. edu.my/ojums/index.php/mjbe/ article/download/1077/706

11. Hussain, J., Mahmood, S., \& Scott, J. (2018). Gender, Microcredit And Poverty Alleviation In A Developing Country: The Case Of Women Entrepreneurs In Pakistan. Journal of International Development. https://doi. org/10.1002/Jid.3403 
12. Idris, A. J., \& Agbim, K. C. (2015). Micro-Credit as a Strategy for Poverty Alleviation among Women Entrepreneurs in Nasarawa State, Nigeria. Journal of Business Studies Quarterly, 6(3), 122-143. Retrieved from http:// search.ebscohost.com/login.aspx? direct $=$ true $\& \mathrm{db}=\mathrm{buh} \& \mathrm{AN}=10177$ 0179\&site $=$ ehost-live

13. Khan, W., Shaorong, S., \& Ullah, I. (2017). Doing business with the poor : the rules and impact of the microfinance institutions. Economic Research-Ekonomska Istraživanja, 30(1), 951-963. https://doi.org/10.1080/133167 7X.2017.1314790

14. Lawin, K. G. (2018). The Impact of Microcredit on Farms and Rural Household: A Literature Review of Experimental Studies.

15. Mazumder, S. U. M., \& Wencong, L. (2013). Micro-Credit and Poverty Reduction: A Case of Bangladesh. Prague Economic Papers, 22(3), 403-417. https://doi. org/10.18267/j.pep.459
16. Milles, Matthew B., \& Huberman, A. M. (2009). Analisis Data Kualitatif, Edisi Terjemahan. Jakarta: Universitas Indonesia Press.

17. Puspita, P. (n.d.). Upaya-Upaya Penyelesaian Kredit Macet Oleh Lembaga Perbankan Terhadap Debitur Wanprestasi (Studi di Bank Tabungan Pensiunan Nasional Cabang Pasar Legi Surakarta). Jurnal Hasif Riset. Retrieved from https://www.e-jurnal.com/2014/12/ upaya-upaya-penyelesaian-kreditmacet.html

18. Robinson, M. S. (2001). The Microfinance Revolution, Sustainable Finance for the poor. Washington, D.C.: The World Bank.

19. Saefullah, K. (2018). From Microfinance To "Gintingan": Reinventing Local Institutions for Poverty Reduction in Indonesia. PEOPLE: International Journal of Social Sciences, 4(1), 591610. https://doi.org/10.20319/ pijss.2018.41.591610
20. Statistik, B. P. (2014). Statistik UMKM. Jakarta. Retrieved from Www.bps.go.id

21. Sumodiningrat, G. (2003). Peran Lembaga Keuangan Mikro Dalam Menanggulangi Kemiskinan Terkait Dengan Kebijakan Otonomi Daerah.

22. Tammili, F. N. M., Mohamed, Z., \& Terano, R. (2018). Effectiveness of the Microcredit Program in Enhancing Micro-Enterprise Entrepreneurs' Income in Selangor. Asian Social Science, 14(1), 7178. https://doi.org/10.5539/ass. v14n1p71

23. Wardana, I. G. K., Yuniarta, G. A., \& Prayudi, M. A. (2017). Pengendalian Internal Terhadap Pemberian Kredit Mikro Usaha Kecil Menengah Di Lembaga Perkreditan Desa (Lpd) Desa Tamblang. E-Journal S1 Ak Universitas Pendidikan Ganesha, 8(2). Retrieved from https:// ejournal.undiksha.ac.id/index.php/ S1ak/article/view/14738 